\title{
POSSESSION OF NUCLEAR WEAPONS - BETWEEN LEGALITY AND LEGITIMIZATION
}

\author{
Tomasz Srogosz \\ Jan Długosz University in Czestochowa, \\ Polish Instytut of Administration, Poland \\ tomasz@srogosz.eu
}

SROGOSZ, Tomasz. Possession of nuclear weapons - between legality and legitimization. International and Comparative Law Review, 2016, vol. 16, no. 1, pp. 7-21. DOI: 10.1515/iclr-2016-0001.

\begin{abstract}
Summary: Recently in Russian policy there was a return to the Cold War practices, which include, inter alia, nuclear deterrence, and even threatening to use nuclear weapons. That policy, however, is carried out in the changed international space compared with the times of the Cold War. The period of detente in relations between world powers was dominated inter alia by discussion on the humanitarian intervention. Human rights, tied to the value of justice, become the most important component of international order. Thus, justice has become the value of the international legal order equivalent to peace. In such a reality, the legitimacy of nuclear weapons should be based not only on the deterrence, but also on the need to protect human rights, tied with justice. Possession of nuclear weapons per se is contrary to this value. This fact should be taken into account in the world powers' policies. Banning nuclear weapons, in accordance with the Radbruch formula, should be a result of these policies.
\end{abstract}

Keywords: nuclear weapons, legality, legitimization, cold war, deterrence, peace, justice.

We have a legal and moral obligation to rid our world of nuclear test and nuclear weapons.

(Ban Ki-moon, Vienna, $17^{\text {th }}$ February 2012)

\section{Introduction}

The terrifying vision of a destructive nuclear war did not vanish when the Cold War ended. The thaw of the 1990s, manifest in improved relations between great nuclear powers, induced a relaxation within the international community. The turn of the $21^{\text {st }}$ century was marked by war on terror, humanitarian aid or rebuilding fallen states. The narrative of the international debate was focused on human rights. No one expected that the world would ever return to the cold war rhetoric, where nuclear weapons constituted the basic component of the imperial policy. Meanwhile, the events which took place in Crimea and in the Eastern 
Ukraine made the history come full circle, making the international community face the problem of a possible nuclear war yet again. Russia has returned to the traditional Soviet policies. Restored were the long-distance journeys of aircrafts carrying nuclear payload. Ever more frequently, Russian politicians mention nuclear weapons in the context of "defense" of Crimea or the Russian relations with the Baltic states. The United States have also been forced to dust off and inventory their nuclear stock. The confrontation between Russia and the US, being a throwback to the Cold War era, is further worsened by the unforeseeable nuclear policy of North Korea.

Such political climate inspires a deeper reflection on the sense, or rather nonsense, of possessing nuclear weapons. This consideration may hardly be deemed to be reflected in the 1996 ICJ advisory opinion on the legality of use of nuclear weapons ${ }^{1}$, which left a feeling of dissatisfaction resulting from the positivist approach adopted by the judges. It would appear that the international community is not yet ready to express its outright protest against possession of a nuclear arsenal by certain states. Most detrimental appears the lack of decision on the possibility of using nuclear weapons in situations where the existence of a state is at risk. The Court's indecision allows to presume that the international law permits the possession of nuclear weapons but not their dissemination. ICJ's position still constitutes a moral encouragement for politicians to demonstrate the nuclear potential of their countries. In mid-2014, the Marshall Islands filed complaints with the ICJ against all states possessing nuclear weapons, which revived the hopes that the perspective would change. Yet, only three of those states had previously subjected themselves to the jurisdiction of the ICJ under Art. 36(2) (the United Kingdom, Pakistan and India) ${ }^{2}$. When considering the above-described circumstances, it appears worthwhile to resurrect the discourse about nuclear weapons. What is of essence here is the method. If the discussion is to be purely positivist, any possible deliberations on the ICJ's advisory opinion seem to be pointless. This is why it is not only the issue of legality, but also of the legitimization of owning nuclear weapons, that is worth attention. Possession of such weapons by certain countries raises the question whether the international

1 Legality of the Threat or Use of Nuclear Weapons, Advisory Opinion, I.C.J. Reports (1996), p. 226.

2 Application instituting proceedings against the United Kingdom submitted on 24 April 2014 by the Republic of the Marshall Islands to the International Court of Justice re obligation to pursue in good faith and conclude negotiations leading to nuclear disarmament, available at http://www.icj-cij.org/docket/files/160/18296.pdf; Application instituting proceedings against Pakistan submitted on 24 April 2014 by the Republic of the Marshall Islands to the International Court of Justice re obligation to pursue in good faith and conclude negotiations leading to nuclear disarmament, available at http://www.icj-cij.org/docket/files/159/18294. pdf; Application instituting proceedings against the Republic of India submitted on 24 April 2014 by the Republic of the Marshall Islands to the International Court of Justice re obligation to pursue in good faith and conclude negotiations leading to nuclear disarmament, available at http://www.icj-cij.org/docket/files/158/18292.pdf. 
law defines the right to own nuclear weapons or prohibits it. If such right exists, is it legitimized? When making the final attempt at approaching the problem of possession of nuclear weapons, Radbruch formula may prove helpful. For one cannot help but agree that lex iniusta non est lex.

\section{Legality}

The right to possess nuclear weapons is a fait accompli. The research leading to the development of nuclear weapons began during World War II. Their principal objective was to gain overwhelming advantage, decisive of the outcome of the conflict. It is commonly accepted that the interest in nuclear power as a method of political combat increased as a result of Albert Einstein's letter of 2nd August 1939, addressed to President Roosevelt, where the renowned physicist expressed his concern about the possibility of the deadly weapon falling in the hands of the Nazis. The Second World War was marked by the nuclear arms race between the US, Germany and the Soviet Union. The goal was to build and detonate an atomic bomb, consequently succeeding in gaining advantage in the still crystallizing balance of power. Germany's defeat left only two superpowers on the battlefield. Both of them had managed to finish their works on the nuclear weapon in a short time. The first explosions were conducted by the US (test of $16^{\text {th }}$ July 1945 and two explosions in Hiroshima and Nagasaki of $6^{\text {th }}$ and $9^{\text {th }}$ August 1945). The Soviet Union detonated its first nuclear payload four years later, on $29^{\text {th }}$ August 1949. The group of nuclear powers was subsequently joined by the United Kingdom ( $3^{\text {rd }}$ October 1952), France ( $13^{\text {th }}$ February 1960$)$, and China (16 $6^{\text {th }}$ October 1964). Consequently, on $1^{\text {st }}$ July 1968, London, Washington and Moscow signed the Non-Proliferation Treaty (NPT) ${ }^{3}$.

Nearly 25 years passed from the explosion of the first nuclear bomb to the NPT effective date. It may be deemed the first international document forbidding the possession of nuclear weapons by the so-called non-nuclear-weapon states which become Parties to the Treaty. The nuclear-weapon states (possessing nuclear weapons as of the date of executing the NPT) were obliged to disarm completely (with no time limits!). Thus, the Treaty sanctioned the existing state of affairs by attesting the nuclear powers' right to possess nuclear weapons. Despite common acceptance of the NPT (until now, 191 countries have joined the Treaty), there is no doubt that the prohibition to possess nuclear weapons by the non-nuclear-weapon states is not customary, which may be inferred from the 1996 ICJ advisory opinion. The Court noted that the international community remained deeply divided by the question whether refraining from using nuclear weapons after 1945 constitutes an opinio iuris. Therefore, the ICJ found no grounds to confirm the customary law in the area of prohibition to use nuclear weapon. Creation of a customary norm was supposedly hampered by the deeply rooted deterrence doctrine, according to which using nuclear weapons would

3 U.N.T.S., roč. 729, p. 161; Effective date: $5^{\text {th }}$ March 1970 
be allowed as the exercise of the right to self-defense against an armed attack "threatening the vital security interests of the State" use or threaten to use nuclear weapons is not of a customary nature, then the prohibition to possess such weapons is not customary either.

The discourse on the legality and legitimization of possessing nuclear weapons would certainly be facilitated by adopting an approach of forcing a commonly accepted custom with regard to the prohibition of threatening or using such weapons or the obligation to disarm. Worth considering are the deliberations of R. A. Weise, who claims that the evidence supporting a uniform and common practice and opinio iuris is contained in numerous resolutions of the UN General Assembly and Security Council, treaties, actions of states, and the "underlying logic of the ICJ Nuclear Opinion". According to R. A. Weise, despite the fact that the ICJ failed to find the reasons to consider nuclear weapons illegal under the customary law, the evidence that has come to light since then does lead to the conclusion that a customary norm was formed ${ }^{5}$. The above-raised arguments, however, are based on frail foundations, which is evidenced by the contemporary practice of the nuclear-weapon states. In the proceedings pending before the ICJ, the US expressly objected treating a possible prohibition to use nuclear weapons as customary, which was explicitly confirmed by the Court in its opinion (it proves difficult to discern the custom based on the "underlying logic" of the opinion, since the ICJ unequivocally denied the customary nature of the prohibition to threaten or use nuclear weapons). Subsequent US actions do not allow much room for certainty as to the existence of a binding norm in this scope. Besides, last months have clearly showed the sad reality of the great powers restoring their nuclear deterrence policies. The German Foreign Minister, addressing the Bundestag on $4^{\text {th }}$ March 2015, said the American nuclear weapons would remain in the territory of Germany, and noted that the process of nuclear disarmament had suffered a regress.

Illegality of using - and thus, of possessing - nuclear weapons could also stem from its violation of the general principles of the international law. This is claimed by Ch. J. Moxley Jr., J. Burroughs and J. Granoff, who invoke a 1976 manual on international law for the US armed forces, which states that using certain types of arms could be illegal as a result of a violation of not only treaties or custom, but also of the "general principles of the law of war", which include the rules of proportionality, discrimination and military necessity ${ }^{6}$. This approach, however, appears to omit the chief themes of the 1996 ICJ advisory opinion, where the Court allowed the use of nuclear weapons in self-defense to the extent

$4 \quad$ Legality..., supra note 1, p. 255.

5 WEISE, Rachel. How Nuclear Weapons Change the Doctrine of Self-Defense. International Law and Politics. 2012, roč. 44, pp. 1353-1361.

6 MOXLEY, Charles Jr., BURROUGHS, John, GRANOFF, Jonathan. Nuclear Weapons and Compliance with International Humanitarian Law and the Nuclear Non-Proliferation Treaty. Fordham International Law Journal, 2011, roč. 34, pp. 670-671. 
it was justified by the military proportionality and necessity. Above all, the Court deemed those two principles to constitute common customary law, and concluded that the principle of proportionality must not, in itself, exclude the possibility to use nuclear weapons in self-defense in any case. Using nuclear weapons ought to remain in accordance with the principles of the international humanitarian law (i.e., in particular with the principles of proportionality, military necessity and discrimination). Despite the fact that, as a general rule, the use of nuclear weapons violates the principles of the humanitarian law, the Court failed to strictly prohibit it in situations where the survival of a State would be at stake ${ }^{7}$.

Therefore, the prohibition to possess nuclear weapons results from a mosaic of international treaties, accession to which is each state's free choice. A contrario, the right to possess nuclear weapons is granted to those states which refused to be bound by the Non-Proliferation Treaty (of much significance here appears to be Art. X of the NPT, allowing a signatory to withdraw from the Treaty if it considers that its superior interests are jeopardized). Apart from the NPT, such obligations result from certain treaties of regional application, such as the Treaty for the Prohibition of Nuclear Weapons in Latin America (Tlatelolco, $14^{\text {th }}$ February 1967$)^{8}$, the South Pacific Nuclear Free Zone Treaty (Rarotonga, $8^{\text {th }}$ August $1986)^{9}$, the Southeast Asia Nuclear-Weapon-Free Zone Treaty (Bangkok, $15^{\text {th }}$ December 1995) ${ }^{10}$, the African Nuclear-Weapon-Free Zone Treaty (Pelindaba, $11^{\text {th }}$ April 1996) ${ }^{11}$, and the Treaty on a Nuclear-Weapon-Free Zone in Central Asia (Semipalatinsk, $8^{\text {th }}$ September 2006) ${ }^{12}$. Under the aforementioned treaties, Nuclear-Weapon-Free Zones (NWFZs) were established, their source lying in Art. VII of the NPT, allowing that groups of states conclude regional treaties in order to ensure total absence of nuclear weapons in their respective territories. All listed treaties include termination clauses. Some of them permit termination in circumstances where the vital interests of a state are at risk (the Treaties of Tlatelolco, Semipalatinsk and Pelindaba), while others - in the event of violation of the terms and conditions of the relevant Treaty by another state (the Treaties of Rarotonga and Bangkok).

In the international law, the scope of authorization to possess nuclear weapons is determined by the non-proliferation obligation resulting from the Treaty. The majority of states have decided to be bound by the prohibition to possess nuclear weapons chiefly due to their limited financial or technological resources. This applies to non-nuclear-weapon states Party to the NPT and to states located in the NWFZs. Nevertheless, what should be emphasized is that such prohibition is not strict or permanent. For the right to possess nuclear weapons is rooted in

$7 \quad$ Legality..., supra note 1, p. 266.

8 U.N.T.S., roč. 634, p. 326; Effective date: 22nd April 1968.

9 U.N.T.S., roč. 1676, p. 223; Effective date: 11th December 1986.

10 U.N.T.S., roč. 1981, p. 129; Effective date: 27th March 1997.

11 International Legal Materials, roč. 35, p. 698; Effective date: 15th July 2009.

12 U.N.T.S., roč. 2212, p. 257; Effective date: 21st March 2009. 
the continuously invoked deterrence doctrine, manifest in the ICJ opinion and international treaties. In order to start the process aimed at developing a nuclear weapon, a non-nuclear-weapon state (as defined in the NPT) could always use the argument of the sovereign and undisputable right to self-defense in extraordinary circumstances, jeopardizing its supreme interests. This opportunity, offered by Art. X of the NPT, was used by North Korea, when, on $10^{\text {th }}$ January 2003, it declared to the parties to the NPT and to the UN Security Council that it was withdrawing from the NPT. Withdrawal was effective as of $10^{\text {th }}$ April 2003. Also, it is no secret that certain states, due to their nuclear ambitions, did not accede to the NPT (India, Pakistan, Israel). To conclude, both the nuclear-weapon states, as defined in the NPT (obliged to disarm in good faith but with no time limits), and the states who are not parties to the NPT (not bound by any international treaty pertaining to the matter at hand) do possess nuclear weapons in compliance with the international law (lawfully) ${ }^{13}$.

One issue remains to be considered, namely, the question of legality of possessing and using nuclear weapons from the perspective of human rights, deeply rooted in the ius in bello in the form of the international humanitarian law (IHL). Protection of civilians during armed conflicts and the right to life, included in the 1949 Geneva Convention ${ }^{14}$, prove to be an undeniably essential part of the IHL. The right to life is imprescriptible, which means that the obligation to observe it in times of peace is not subject to revocation in the event of an armed conflict. At the same time, IHL prohibits the use of combat assets causing unnecessary suffering. In consequence, according to the common customary law, using and possessing chemical or biological weapons is illegal, as it goes against the principles of humanitarianism and discrimination between the civilians and the combatants ${ }^{15}$. Nevertheless, the International Court of Justice unanimously ruled that "a threat or use of nuclear weapons should also be compatible with the requirements of international law applicable in armed conflict, particularly those of the principles and rules of international humanitarian law", and subsequently, by seven votes to seven, by the President's casting vote, stated that it followed "from the above-mentioned requirements that the threat or use of nuclear weapons would generally be contrary to the rules of international law applicable in armed conflict, and in particular the principles and rules of the international humanitarian law"16. Having so concluded, the ICJ did not exclude the possibility of using nuclear weapon "in an extreme circumstance of self-defence, in which the

13 Cf.: RUBIN, Alfred. Nuclear Weapons and International Law. The Fletcher Forum, 1984, roč. 8 , p. $48-49$.

14 Convention relative to the protection of civilian persons in time of war, U.N.T.S., roč. 75, p. 287; Effective date: $21^{\text {st }}$ October 1950.

15 Cf.: JOYNER, Daniel H. International Law and the Proliferation of Weapons of Mass Destruction. Oxford: Oxford University Press, 2009, p. 90; GAZZINI, Tarcisio. The Changing Rules on the Use of Force in International Law. Manchester: Manchester University Press, 2005, pp. 222-223.

16 Legality..., supra note 1, p. 266. 
very survival of a State would be at stake". According to the ICH, possessing and using nuclear weapons in extraordinary situations is therefore legal, even despite its non-compliance with the IHL, based on the principles of humanitarianism and discrimination between civilians and combatants. Such approach results from other principles of IHL, namely those of proportionality and necessity ${ }^{17}$.

Fiat iustitia, pereat mundus?

\section{Legitimization}

The above-quoted maxim was supposedly coined by Emperor Ferdinand I. As it is an expression of an extreme positivist approach, it gained particular importance in the $20^{\text {th }}$ century. Strict observance of the applicable international law, at all costs and with no regard to the consequences, truly has the potential to make the world perish (pereat mundus) and leave no one who would continue pondering upon the legality and legitimization of using or possessing nuclear weapons. Ironically, the maxim itself has become so real that it now inspires a deeper consideration of the values of the international law. Is it not so that, in the times of prospective nuclear war, peace, taken as a value inscribed in the Charter of the United Nations, encompasses the imperative of survival of the human kind? Has the world, and the international law, not changed after the end of the Cold War? Has such change not been essentially influenced by the basic human rights? Perhaps, it is worthwhile to stop for a while and listen to people of authority, the most convincing of whom took part in the development and detonation of nuclear and thermonuclear bombs. These include the physicist Robert Oppenheimer and the Soviet physicist Andrei Sakharov, who, having witnessed nuclear testing, became ardent opponents of nuclear weapons. The reason for this change of heart lies, most probably, in the noticeable consequences of using said arms, which exceeded the scientists' expectations. This is why a perfect introduction to deliberations on the legitimization of possessing nuclear weapons is offered by one of the accounts describing the day of the biggest nuclear test at the Bikini Atoll, often referred to as the "day of two suns":

I thought I saw what appeared to be the sunrise, but it was in the west. It was truly beautiful with many colors-red, green and yellow-and I was surprised. A little while later the sun rose in the east. Then some time later something like smoke filled the entire sky and shortly after that a strong and warm wind-as in a typhoon-swept across Rongelap. Then all of the people heard the great sound of the explosion. Some people began to cry with fright. Several hours later the powder began to fall on Rongelap. (account of

17 Ibid., at 245; see: MAHMOUDI, Said. The International Court of Justice and Nuclear Weapons. Nordic Journal of International Law, 1997, roč. 66, p. 85. 
John Anjain of the Rongelap Atoll, located approximately $220 \mathrm{~km}$ of the test site of $1^{\text {st }}$ March 1954) ${ }^{18}$.

We must bear in mind that the above-quoted description comes from the Cold War period, when nuclear, including thermonuclear, weapons were the chief instrument of the deterrence policy. However, we are now witnessing a restoration of those practices. The nuclear rhetoric is present mainly in the Russian political narrative. The Cold War has been brought back to a different international reality and, what follows, to a different international law. The turn of the $21^{\text {st }}$ century was not a normative or axiological vacuum. During the "Cold War pause", the international community focused its attention, in particular, on the dilemmas of humanitarian intervention. The axis of discussion ran between the use of force and the protection of human rights. This gave rise to the issue of legality and legitimization of humanitarian intervention, enveloped in the question whether use of force is allowed for the purpose of protection of human rights if such use is not legal, therefore, initiated without the authorization of the UN Security Council. In other words, is an illegal humanitarian intervention permissible in situations where it is legitimate? In its report, the Independent International Commission on Kosovo concluded that "the NATO military intervention was illegal but legitimate"19. Antinomy appears to be the key to the phrase "illegal but legitimate" 20 . The strictly positivist perspective of the international law lost its raison dêtre. Ever more frequent became the positions of seeking legitimization of the international law in the sphere of values from outside of the international legal system (Grotian tradition of the international law) or considering the international law as based on the values formed within this system ${ }^{21}$. It seems doubtless that the importance of the values constituting the foundations of the international law increased at the turn of the $21^{\text {st }}$ century. This was connected with a change of perspective - the point of reference for the international legal order became the human, who superseded the state. In essence, this change concerned the beneficiary of the international law, which began to be applied to humans in the first place. As pointed out by J. Zajadło, the traditional "statism", placing a state at the focal point, was expelled by the approach of admitting the

18 DIBBLIN, Jane. U.S. Nuclear Testing and the Pacific Islanders. Days of Two Suns, New York: New Amsterdam Books, 1990, p. 25. The ball of fire caused by the explosion had a diameter of $100 \mathrm{~km}$, and was visible from $450 \mathrm{~km}$ distance. Note that this was not the biggest nuclear explosion recorded so far. On $30^{\text {th }}$ October 1960, the Soviet bomb named “Tsar" was detonated. The explosion was visible from approximately $1000 \mathrm{~km}$ distance. The heat radiation resulting from the explosion could cause third degree burns to people located $100 \mathrm{~km}$ away from the detonation site.

19 Independent International Commission on Kosovo. The Kosovo Report. Conflict, International Response, Lessons Learned. Oxford: Oxford University Press 2000, p. 4.

20 See: R. Kwiecień, who distinguishes the following antinomies: illegal but legitimate and legal but illegitimate (KWIECIEŃ, Roman. Teoria i filozofia prawa międzynarodowego. Problemy wybrane. Warsaw: Difin, 2011, p. 131).

21 Ibid., p. 195. 
subjectivity of a human being ${ }^{22}$. This change of views on the role of the international law was noticed at the threshold of the new millennium, when attention was brought to the evolution of the notion of security, which was no longer perceived solely as the security of a state, but also as humanitarian security ${ }^{23}$.

The above-described axiological trends in the international law may, or even must, affect the assessment of the issue of possessing and using nuclear weapons. Ironically, the discourse on the legality and legitimization of humanitarian interventions could have taken its toll on the discussion about nuclear weapons. Its context has changed since the humanitarian intervention in Yugoslavia. Legitimization, or the values of the international law, must be born in mind principally in situations where a military response and the protection of human rights are at stake. This applies to both humanitarian intervention and the use (possession) of nuclear weapons. In the case of humanitarian interventions, the dilemma boils down to the possibility of using force due to violation of human rights on a massive scale (catastrophic humanitarian crisis). In the case of nuclear weapons, the problem consists in the possibility of military response involving the use of nuclear weapons despite violation of human rights on a massive scale (catastrophic humanitarian crisis). In the first case scenario, a military response is the result of mass violations of human rights, in the second - it is their reason. This discourse takes place in the same axiological and international legal reality, delineated by the values of peace and justice.

Maintaining international peace and security is the supreme objective of the United Nations (Art. 1(1) of the Charter of the United Nations). Simultaneously, peace is an axiological foundation of the contemporary international order ${ }^{24}$. Peace can be perceived in a negative and positive dimension. Its negative perception brings peace down to a state where there are no armed conflicts, which is achieved through preventive diplomacy, conflict resolution or peacekeeping. The positive perception of peace endows that same state with such values as peacebuilding, i.e., building states ${ }^{25}$. An expression of the negative approach to peace is manifest in Art. 2(4) of the UN Charter, which prohibits the threat or use of force in international relations, while the positive approach is visible in Art. 55 of the Charter, which imposes an obligation to, inter alia, promote universal respect for human rights. The positive perspective entails the value of justice, which, in the contemporary international legal order, is connected with respect for human rights.

22 ZAJADŁO, Jerzy. Legalność i legitymizacja interwencji humanitarnej. Państwo i Prawo, 2004, č. 1, p. 10.

23 See: e.g.. COMMISSION ON HUMAN SECURITY. Human Security Now. New York, 2003, p. 2; Report of the International Commission on Intervention and State Sovereignty. The Responsibility to Protect. Ottawa: International Development Research Centre, 2001, p. 6.

24 KWIECIEŃ, Roman. Teoria..., supra note 20, p. 195.

25 Cf.: SANDOLE, Dennis J. D. Peace and Security in the Postmodern World. The OSCE and Conflict Resolution. London - New York: Routledge, 2007, p. 43. 
The above-described notion of peace introduces chaos to the axiological sphere of the international law. Do we mean one single value, which is peace in its positive meaning? Or do we mean two, sometimes opposed, values of peace and justice? Peace in its positive meaning, in fact perceived as "just peace", is an unattainable idea ("orientation standard for the interpretation of the international law") for which we may only strive continuously ${ }^{26}$. The state of "just peace" is impossible to achieve, which may a have a somewhat demoralizing effect on the members of the international community. For, if it is unattainable, why bother trying? The analogy to the mythical toil of Sisyphus jumps to mind. More value is presented by the negative meaning of peace. Riddance of armed conflicts appears within reach of the international community. Therefore, we need to assume the coexistence of two values - peace and justice - around which revolved the discourse on the dilemmas of humanitarian interventions ${ }^{27}$.

During the Cold War, peace was an unquestionable value of the international order. Part of that order - the nuclear weapon - being the instrument of the deterring policy, played a stabilizing role. Legitimization of nuclear weapons was based on the deterrence doctrine. The fear of the cruelty and the possible consequences of military confrontation between nuclear powers ensured relative security for the international community divided into two blocs. Ironically, the arms race contributed to international balance. The end of the Cold War forced the international community to face new challenges in the area of international peace and security. Due to an erosion of the deterrence policy, the question of possessing nuclear weapons appeared in a different context, related to the definition of the international order (multipolarity or unipolarity?) or the threat of nuclear weapons being intercepted by terrorist organizations. At the same time, another problem appeared, concerning the new function of nuclear weapon, since it was devaluated as a deterrence tool. It was already in the new international reality that the ICJ allowed the possibility of using nuclear weapons in extraordinary circumstances, endangering the very survival of a state. Thus, the ICJ made a reference to the Cold War deterrence policy. One may think, the Court issued its opinion while still in the shackles of the Cold $\mathrm{War}^{28}$. In this context, pos-

26 Cf.: SKORDAS. Achilles. "Just Peace" Revisited: International Law in the Era of Asymmetry. In STETTER, Stephen (ed.). Territorial Conflict in World Society. Modern Systems Theory, International Relations and Conflict Studies. London-New York: Routledge, 2007, pp. 151-152.

27 Cf.: KWIECIEŃ. Roman. Teoria..., supra note 20, p. 193; ZAJADŁO, Jerzy. Dylematy humanitarnej interwencji. Historia-etyka-polityka-prawo. Gdańsk: Arche, 2005, p. 27.

28 "Furthermore, the Court cannot lose sight of the fundamental right of every state to survival, and thus its right to resort to self-defence, in accordance with Article 51 of the Charter, when its survival is at stake. Nor can it ignore the practice referred to as "policy of deterrence" to which an appreciable section of the international community adhered for many years (...). Accordingly, in view of the present state of international law viewed as a whole, as examined above by the Court, and of the elements of fact at its disposal, the Court is led to observe that it cannot reach a definitive conclusion as to the legality or illegality of the use of nuclear weapons by a State in an extreme circumstance of self-defence, in which its very survival would be 
sessing nuclear weapons remains in compliance with the value of peace, taken as a worldwide-conflict-free state, serving as a "stabilizer" of international relations. Nevertheless, we must not forget that the turn of the $21^{\text {st }}$ century brought about new threats to the international order, resulting from a breakdown of the bipolar order, in the form of the so-called failed, failing and rogue states. These include North Korea who, as mentioned previously, is in lawful possession of nuclear weapons. Revival of the Cold War requires that the deterrence doctrine be applied in a different international reality, whose bipolarity is not so obvious anymore. Nuclear threat is no longer posed solely by the participants in the Cold War, but also by unpredictable states, whose policies cannot be accommodated within said confrontation. Nuclear weapons were somehow incorporated into the relations of the bipolar world. The political complexity of the modern world (its multipolarity, terrorism, symptoms of the Cold War revival, failed and rogue states, success of the jihadi movement) inspires reflection on the meaning of nuclear weapons. The deterrence doctrine was to a certain extent predictable in the $20^{\text {th }}$ century. In the $21^{\text {st }}$ century, this is no longer the case. This is why it cannot constitute the basis for legitimization of using nuclear weapons. At the same time, we must not think "what if" the ICJ's opinion was issued under the current circumstances or without referring to the deterrence doctrine. However, this raises a question of whether the ICJ would still hesitate as to the legality of using nuclear weapons in extraordinary situations threatening the survival of a state.

Similar uncertainties should not be caused by the reference to the value of protecting human rights (justice). The discourse on humanitarian intervention referred to the iusta causa (just cause), arguing that using force should be allowed for the purpose of preventing mass violations of human rights. In this context, an intervention may prove just. Hence, we could ask: Is it just to possess nuclear weapons (in order to use them)? Neither this question nor the issue of legitimacy of humanitarian interventions were the object of any interest during the Cold War, when the unquestionable value was peace, which should be achieved even at the price of injustice, understood also in terms of violation of human rights by totalitarian regimes. After 1989, these two values have been considered to be of equal rank and placed in opposition to each other on numerous occasions, where humanitarian interventions proved controversial ${ }^{29}$.

Justice, considered as one of the basic values of the international law, is an emanation of the norms which obligate states to protect human rights. Their postwar development, marked by the Universal Declaration of Human Rights, has had an undeniable effect on the shape and application of the national laws in the $21^{\text {st }}$ century. Referring to the terminology of A. Buchanan and D. Golove, J. Zajadło points out that, both in the case of transnational justice and international justice, the final point of reference are the human rights. The power of

at stake" (Legality..., supra note 1, p. 263).

29 See: ZAJADŁO, Jerzy. Dylematy..., supra note 27, p. 27 and the references quoted therein. 
the human rights has had a major influence on the level of transnational justice. However, one trait of the concept of the human rights is their escalation, which proves difficult to be contained. This is why the problem is shifted from the level of transnational justice to the level of international justice, that is to say, from the level of basic principles of universal application to all states and their internal affairs to the level of distributive justice, applicable not to one single state but to the relations between states, groups or residents of different countries. Ever more frequent is the postulate to the fulfill the idea of justice not only within borders, but also beyond borders, or even without borders. International justice based on political realism and formal rules, shaped throughout centuries as "justice among nations", is now more frequently perceived in terms of material global justice or "cosmopolitan justice" ${ }^{\text {" }}$. As stated in the Preamble to the Universal Declaration of Human Rights, "recognition of the inherent dignity and of the equal and inalienable rights of all members of the human family is the foundation of freedom, justice and peace in the world" ${ }^{31}$. Therefore, what lies at the foundation of the human community is not only equality, but also human dignity. This is certainly an achievement of the postwar human rights regulations. As emphasized by M. Piechowiak, acknowledgement of dignity as the foundation of justice by the international law is the acknowledgement of what humans are as the foundation of the law. The author points out that the pre-WW II totalitarian regimes considered that the ultimate reason for the existence of the law and the basis of the legal provisions was not so much the wellbeing of individual humans (relationships between specific people in terms of the goodness which contributes to personal development of a human being) as the normative act (relation of humans and norms), racial or class interests (relation to objectives whose achievement may require that people be treated instrumentally) ${ }^{32}$. Currently, equality should not be perceived as arithmetic or geometric distribution of wealth. Wealth distribution always takes place in specific circumstances ensuing from human dignity. Hence, the interpretation of Aristotle's idea of justice is based on the fact that "the formal rules referring to equality determined $<$ in terms of the object $>$ are secondary to the equality $<$ of us $>$ which assigns the wealth due, bearing in mind a specific individual and his specific circumstances" [own translation] ${ }^{33}$. Presently, the distribution of wealth based on the international law must refer to the human dignity and the right ensuing therefrom. The focal point of the distribution of wealth is the human and his dignity.

30 ZAJADŁO, Jerzy. Teoria sprawiedliwości międzynarodowej: prawa człowieka contra suwerenność. Polski Przegląd Dyplomatyczny, 2005, č. 5, pp. 107-108.

31 Universal Declaration of Human Rights. [online]. Available at http://www.un.org/en/universal-declaration-human-rights/

32 PIECHOWIAK, Marek. Godność i równość jako podstawy sprawiedliwości. Z perspektywy międzynarodowej ochrony praw człowieka. Toruński Rocznik Praw Człowieka i Pokoju, 1992 (1993), roč. 1, p. 38.

33 Ibid., p. 46. 
The value of peace has now, as it had during the Cold War, an interstate dimension - it boils down to maintaining an armed-conflict-free state of affairs. At the same time, peace entails not only international security, but also humanitarian security, by its reference to the value of justice ${ }^{34}$. In consequence, the idea of peace and security, as manifest in the international law, was permeated by the human rights ideology in the 1990s, primarily due to the discussion on the premises of humanitarian intervention. In these circumstances, the Cold War doctrine of deterrence with the use of nuclear arsenal is no longer valid. Nuclear weapons, per se, are a negation of the above-discussed idea of justice. Their potential use would lead to a violation of human rights on a massive scale. Nuclear weapons are weapons of mass destruction (similar to biological and chemical weapons), with the potential of destroying living organisms on a catastrophic scale and causing long-term effects on the natural environment. The specificity of nuclear weapons, differentiating them from conventional arms, lies in the consequences of detonation, in the form of lethal radioactive contamination, comparable to the effects of chemical weapons. Considerable number of victims would die slow agonizing death.

The foregoing arguments prove that the use of nuclear weapons essentially goes against the IHL, which, however, does not necessarily exclude the legality of possessing or using them in extraordinary circumstances (as opposed to chemical and biological weapons, which is strictly prohibited by the common customary law) ${ }^{35}$. Nevertheless, we must not forget that the modern-day international legal order does not exist in an axiological vacuum. Its values stem, inter alia, from the regulations of the IHL and the UN Covenants on Human Rights, drawing from the idea of human dignity. In the $21^{\text {st }}$ century, acknowledging the legality of possessing (or using) nuclear weapons is not a synonym of its legitimization (or compliance with the value of the international law). To sum up, we may say that a lawful possession of nuclear weapons is not legitimate (compliant with the valued of the modern-day international law). What is visible here is the antinomy of "legal but not legitimate". As stated before, in the event of humanitarian intervention without the approval of the UN Security Council, the antinomy of "illegal but legitimate" was present. The common denominator of the foregoing dilemmas of the modern international law is justice, negated by massive violations of the fundamental human rights (on a catastrophic scale).

So, is this the case of fiat iustitia, pereat mundus? Can we still, in the $21^{\text {st }}$ century, accept the fact that some states lawfully possess nuclear weapons in compliance with the international law? Surely, we cannot argue that the posses-

34 Report..., supra note 23, p. 15.

35 Cf.: L. Tien, who is of the opinion that nuclear weapon is per se illegal due to its noncompliant with the IHL (TIEN, Lipin. On the Legality of Development of Nuclear Weapons. National Taiwan University Law Review, 2011, č. 6, pp. 521 et seq.). This approach, however, has not been applied in practice by the nuclear-weapon states or by the ICJ in its 1996 opinion. 
sion of such weapons by democratic states (such as the US) is legitimate, while their possession by non-democratic states (e.g., North Korea) is not. The issue of legitimization involves the relation between possession of nuclear weapons and the human rights and not between the possession of nuclear weapons and the political system. In accordance with the Radbruch Formula, illegitimate possession of nuclear weapons, and, what follows, their illegitimate use, in any circumstances makes such possession or use illegal (lex iniustissima non est lex). We ought to remember, however, that this conclusion is valid if we adopt the naturalist approach. Yet, if we assume that the value of justice, inherent to the modern international law, is somehow a part of the international legal order $^{36}$, we must accept that the possession or use of nuclear weapons is legal. But it was justice that made the nuclear-weapon states agree to complete disarmament in good faith. This obligation stems solely from the binding international treaties. Even if it was customary, failure to specify time limits for such disarmament would inevitably lead to the potential legal norm being ineffective. The assumption of legality of possession of nuclear weapons, despite it going against the value of justice, should be, in the $21^{\text {st }}$ century, considered detrimental to the international community and the international legal system. It is rather a relic of the Cold War period, wherein states were the chief beneficiaries of international legal norms. Such order inspired the ICJ to accept the legality of using nuclear weapons in extraordinary circumstances. As a matter of fact, a contribution to such decision was offered by the international law, whose norms justified - in the opinion of the ICJ - the unfair conclusion manifest in the lack of a strict prohibition. Presently, the acceptance of legality of possession of nuclear weapons within the homocentric international legal order is unconceivable. We should be rather inclined towards the application of the Radbruch formula. In the times of common acknowledgment of human rights, extremely unjust legal norms must not be accepted. A revival of the naturalist approach is an important value, particularly in the unstable international reality in which we now live. Positivism works in times of peace, ensuring legal security. We have recently experienced a return of the Cold War, only this time the doctrine of deterrence seems unable to ensure such security due to the complexity of international relations, consisting, inter alia, in the problem of identifying two antagonistic political blocs. Bearing in mind this condition of the international community, the naturalist approach seems preferable. Otherwise, it may be too late for metamorphosis of opinions and following G. Radbruch, once the potential armed conflict breaks out. Illegality of possessing nuclear weapons must be strongly affirmed, as it goes against the idea of justice.

This is why we should be enthusiastic about the initiative of the Marshall Islands, who filed complaints against all states possessing nuclear weapons, accusing them, amongst other things, of "a flagrant denial of human rights" by

36 See: KWIECIEŃ, Roman, Teoria..., supra note 20, p. 195. 
delaying their complete disarmament. Unfortunately, only three of those states acknowledged the ICJ's jurisdiction under Art. 36(2) of the ICJ Statute (the United Kingdom, India and Pakistan). It is possible that the International Court of Justice will rule that the Marshall Islands are not a legitimate applicant in these three cases, as they could only have a case against the United States for their nuclear tests at the Bikini and Enewetak Atolls. Regardless of the outcome, we should demand that the non-nuclear-weapon states adopt a more active approach towards asserting the illegitimacy, and thus - illegality, of possessing nuclear weapons. Some assistance is offered by the naturalist approach whose early signs are visible in the position of the Marshall Islands. An important role in the potential change of attitude towards nuclear weapons will be played by those states who already have them, in particular, by the US. By continuing their Cold War policy of deterrence, they are allowing states, such as North Korea, a possibility to justify their works on a nuclear arsenal. Delegitimation and, consequently, delegalization, of nuclear weapons in the American or Russian policy (following the chemical and biological weapons) would certainly support negotiations with Iran or North Korea. 